\title{
PEMBEBANAN HAK TANGGUNGAN DALAM PEMBERIAN KREDIT PADA LEMBAGA PERKREDITAN DESA (LPD)
}

\author{
I Nyoman Agus Saputra, I Nyoman Putu Budiartha, Ni Gusti Ketut Sri Astiti \\ Fakultas Hukum Universitas Warmadewa, Denpasar-Bali, Indonesia
}

\begin{abstract}
Abstrak
Pada tahun 1984, Pemerintah Provinsi Bali mengeluarkan suatu gagasan untuk membantu desa pakraman dalam menyelenggarakan fungsi kebudayaan. Melalui Surat Gubernur Nomor 972 tahun 1984, 1 November 1984 tentang Lembaga Perkreditan Desa. Penelitian ini bertujuan untuk menjelaskan sistem pemberian kredit pada Lembaga Perkreditan desa dengan jaminan hak tanggungan dan menjelaskan upaya hukum terhadapa nasabah yang tidak melaksanakan kewajiban seperti yang dituangkan dalam perjanjian kredit. Penelitian ini didesain dengan penelitian normatif, sumber bahan hukum terdiri dari bahan hukum primer dan sekunder. Analisis bahan hukum melalui analisis interpretasi. Hasil penelitian menunjukkan $\mathrm{p}$ emberian kredit pada Lembaga Perkreditan desa dengan jaminan hak tanggungan, dituangkan dalam perjanjian kredit antara LPD dan nasabah yang diwajibkan juga mendapat persetujuan dari Bendesa adat, dalam hal ini untuk menerapkan sanksi adat ketika terjadi kredit macet. Sanksi adat adalah sebagai upaya yang terakhir setelah upaya-upaya lain tidak berhasil dengan tujuan agar penunggakan kredit dapat dilunasi kembali dan nasabah kredit yang macet tidak melaksanakan kewajiban seperti yang dituangkan dalam perjanjian kredit diberi sanksi sita jaminan yang diikat dengan pembebanan hak tanggungan untuk benda tidak bergerak. Tentu ini disesuaikan dengan peraturan Gubernur Provinsi Bali Nomor 44 Tahun 2017 mengikat terhadap pembebanan hak tanggungan dalam pemberian kredit pada LPD yang hanya berlaku terhadap Desa adat setempat, dalam hal ini LPD merupakan suatu badan usaha simpan pinjam yang dimiliki oleh desa adat
\end{abstract}

Kata Kunci: Hak Tanggungan; Pemberian Kredit; Nasabah

\begin{abstract}
In 1984, the Provincial Government of Bali issued an idea to assist Pakraman villages in carrying out cultural functions. Through Governor's Letter Number 972 of 1984, November 1, 1984 concerning Village Credit Institutions. This study aims to explain the system of providing credit to village credit institutions with guarantee of mortgage rights and to explain legal remedies against customers who do not carry out the obligations as outlined in the credit agreement. This research was designed with normative research, the source of legal materials consisted of primary and secondary legal materials. Analysis of legal materials through interpretation analysis. The results of the study show that the provision of credit to village credit institutions with guarantees of mortgage rights is stated in the credit agreement between the LPD and customers who are required to also receive approval from the customary Bendesa, in this case to apply customary sanctions when bad credit occurs. Customary sanctions are the last resort after other efforts are unsuccessful with the aim that credit arrears can be paid back and bad credit customers do not carry out the obligations as outlined in the credit agreement are given sanctions for confiscation of collateral bound by imposition of mortgage rights for immovable objects. Of course this is adjusted to the regulation of the Governor of Bali Province Number 44 of 2017 binding on the imposition of mortgage rights in providing credit to the LPD which only applies to local customary villages, in this case the LPD is a savings and loan business entity owned by a traditional village.
\end{abstract}

Keywords: Mortgage Rights; Lending of Credit; Customer

\section{PENDAHULUAN}

Munculnya lembaga keuangan pada umumnya dan khususnya di Desa pakraman Kerobokan Kabupaten Badung Provinsi Bali, menjadi modal awal mendapat bantuan Dana APBD Bali sebesar dua juta. Keputusan gubernur yang mendasari pendirian lembaga kredit desa belum mejnelaskan status kepemilikan lembaga kredit desa, apakah itu milik desa biasa atau desa resmi. Pengawasan tugas -tugas lembaga kredit desa pada waktu itu masih dilakukan oleh Dewan Pengawas Kabupaten. Sementara mempromosikan dan pengawasan teknis lembaga kredit pedesaan dilakukan oleh Bank 
Pembangunan Daerah Bali. Hal ini menyebabkan masalah dengan manajemen, promosi dan pengawasan nya, mengikuti perkembangan pesat aset desa beberapa tahun k emudian.

Lembaga pengkreditan desa mempunyai peranan yang sangat strategis karena selama ini telah melayani Usaha Kecil (selanjutnya disebut UMK) dan masyarakat desa di Bali melalui pelayanan jasa keuangan yang dilakukan sesuai dengan kebutuhan nasabah, yaitu prosedur sederhan a, proses yang singkat, pendekatan personal serta kedekatan lokasi dengan nasabah (Yandani \& Suryanata, 2019). Lembaga ini mengedepankan peraturan-peraturan mengenai hukum jaminan di Indonesia, sebagaimana yang ditentukan oleh Undang - Undang Nomor 10 Tahun 1998 tentang Perbankan, yait u dalam memberikan kredit harus mempunyai keyakinan berdasarkan analisis yang mendalam atas itikad baik dan kemampuan membayar hutang sesuai dengan yang dijanjikan. Tentunya dalam pemberian kredit dengan jumlah yang besar harus disertai juga dengan jaminan, apabila jaminan berupa benda tidak bergerak maka akan tunduk pada ketentuan perundangan tentang Hak Tanggungan, dan apabila jaminan berupa benda bergerak maka akan tunduk pada ketentuan tentang Jaminan Fidusia (Maulana, 2017).

Peneletian sebelumya mengungkapkan bahwa Apa bila debitur atau pelaku kredit sengaja tidak melaksanakan kewajiban sesuai perjanjian akan ditunggu itikad baiknya untuk melakukan pembayaran kepada lembaga pengkreditan desa, jika masih belum bisa terselesaikan secara kekeluargaan maka didakan pelelangan dari jaminan yang telah diberikan diawal melaukan kredit (Wiguna $S$ et al., 2020). Selanjutnya Maulana, (2017) menngukapkan bahwa Penyelesaian kredit macet bisa diselesaikan melalui litigasi maupun non litigasi. Non litigasi lebih dikenal dengan menggunakan sebutan alternatif penyelesaian sengketa di luar pengadilan. Menurut Jayanthi et al., (2016) Lembaga pengkreditan desa dalam status dan kedudukannya sebagai duwe desa pakraman dengan karakteristiknya yang khusus tentu tidak dapat disamakan dengan perseorangan, badan hukum, maupun korporasi, sehingga pengikatan jaminan kreditnya pun harus disesuaikan dengan landasan hukum adat Bali sesuai dengan amanat Undang-Undang Lembaga Keuangan.

Namun dalam kenyatanya tidak semua nasabah yang telah memperoleh kredit mampu melunasi kredit dengan baik dan tepat waktu. Akibatnya menjadikan pengembalian kredit tersebut macet. Maka dari itu setiap pengikatan kredit wajib pada LPD diikat oleh perjanjian jaminan yaitu perjanjian hak tanggungan. Oleh karena itu penelitian ini dilakukan dengan tujuan untuk menjelaskan sistem pemberian kredit pada Lembaga Perkreditan desa dengan jaminan hak tanggungan dan menjelaskan upaya hukum terhadapa nasabah yang tidak melaksanakan kewajiban seperti yang dituangkan dalam perjanjian kredit.

Berdasarkan Peraturan Gubernur Provinsi Bali Nomor 44 Tahun 2017 tentang Peraturan Pelaksanaan Perda Nomor 3 Tahun 2017, bahwa LPD dibolehkan memasang hak tanggungan dalam setiap perjanjian kredit pada LPD. Sedangkan menurut Undang -Undang Nomor 4 Tahun 1996 tentang hak Tanggungan, hanya memberikan pemasangan hak tanggungan bagi setiap Badan Usaha.

\section{METODE PENELITIAN}

Tipe penelitian menggunakan penelitian hukum empiris melalui pendekatan konseptual, pendekatan perundang-undangan dan pendekatan sosiologis. Sumber data didapatkan secara langsung yang berasal dari masyarakat yang dinamakan dengan data primer (data dasar) dan diperoleh dari bahanbahan pustaka dinamakan data sekunder data dikumpulkan dengan metode studi dokumentasi dan wawancara (Soekanto, 2009). Selanjutnya data yang sudah terkumpul dianalisis dengan menggunakan teknik pengolahan data secara kualitatif.

\section{HASIL DAN PEMBAHASAN}

\section{Pemberian Kredit Pada LPD Dengan Jaminan Hak Tanggungan}

Subyek Hak Tanggungan diatur dalam Pasal 8 sampai 9 UUHT, dalam kedua pasal tersebut ditentukan bahwa yang dapat menjadi subjek hukum dalam pembebanan hak tanggungan adalah pemberi hak tanggungan dan pemegang hak tanggungan. Pemberi hak tanggungan dapat seorang atau badan hukum, yang mempunyai kewenangan untuk melakukan perbuatan hukum terhadap obyek hak tanggungan. Pemegang hak tanggungan terdiri dari perorangan ataupun badan hukum yang berkedudukan sebagai pihak yang berpiutang (HS, 2014).

Konsep LPD tidak saja me merankan fungsinya sebagai lembaga keuangan yang melayani transaksi keuangan masyarakat desa, tetapi telah pula menjadi solusi atas 
keterbatasan akses dana bagi masyarakat pedesaan yang notabene merupakan kelompok masyarakat dengan kemampuan ekonomi terbatas. Dalam memberikan kredit diawali penilaian terhadap character (watak), capacity (kemampuan), capital (modal), condition (prospek) dan collateral (agunan) dari debitur (Dahlan Siamat, 1995:99). Dalam perbankan prinsip ini dikenal dengan prinsip 5C, begitu juga halnya dalam Lembaga Perkreditan Desa prinsip ini merupakan dasar dalam pemberian kredit kepada debitur. Adapun penjelasan dari prinsip $5 \mathrm{C}$ tersebut adalah sebagai berikut:

1. Character (watak) Penilaian terhadap watak terutama didasarkan kepada hubungan yang telah dijalin dari pihak lain yang dapat dipercaya. Sehingga dapat menyimpulkan bahwa watak dari debitur tersebut jujur, punya itikad baik serta tidak akan menyulitkan dalam pengembalian kredit di kemudian hari.

2. Capacity (kemampuan) Harus meneliti mengenai keahlian debitur dalam bidangnya usahanya, atau kemampuan debitur dalam mengatur manajemen, sehingga diperoleh rasa yakin bahwa usaha diberikan kredit tersebut dikelola oleh orang yang tepat.

3. Capital (modal) Melakukan analisis terhadap posisi keuangan secara keseluruhan debitur, baik yang ada pada masa sekarang maupun yang akan ada di kemudian hari, sehingga kemampuan modalan debitur dapat diketahui.

4. Condition (prospek) Penilaian terhadap prospek usaha debitur agar dapat mengetahui pemasaran dari usaha debitur tersebut

5. Colleteral (agunan) Menganalisis agunan yang akan digunakan jaminan. Agar di kemudian hari tidak menimbulkan permasalahan dalam eksekusinya, apabila kredit tersebut macet.

\section{Peraturan Gubernur Mengikat terhadap Pembebanan Hak Tanggungan Pemberian Kredit Pada Lembaga Perkreditan Desa}

Salah satu fungsi melaksanakan hukum adat terutama kekuasaan untuk menjatuhkan sanksi khususnya yang menyangkut "Indik Pamidanda" (sanksi) yang pada intinya tidak berbeda. Oleh karena itu selengkapnya akan dikutip salah satunya seperti dalam Pawos Awig-awig Desa Adat dinyatakan:

1. Desa utawi banjar wenang niwakang pamidanda ring warga sane sisip (desa atau banjar berhak menjatuhkan sanksi kepada warga yang salah).

2. Patiwak/metetiwak pamidanda kelaksanayang oleh Bendesa Adat utawi prajuru banjar (Penjatuhan sanksi dilaksanakan oleh Bendesa atau Prajuru Banjar).

3. Bacakan pamidanda luwire (Jenis sanksi seperti) :

a. Ayah-ayah panukun kasisipan (pembayarah ganti kerugian atas kesalahan).

b. Danda arta (dadosan saha panikelnya utawi panikel paturunan) (denda uang seperti dedosan dan kelipatannya atau kelipatan iuran)

c. Pengupakara/pengangaskara (upacara)

d. Rerampagan (penyitaan dan pelelangan)

e. Kadaut tanah ayahan banjar (penarikan tanah ayahan banjar). f. Lan pamidanda siwosan (dan sanksi lainnya).

Ketentuan ini dapat dianalisis bahwa kewenangan menjatuhkan sanksi adat melalui pertemuan desa kepada yang telah melakukan kesalahan seperti pada kasus kredit macet baik selaku nasabah maupun selaku pengurus seperti tersebut di atas merupakan salah satu kekuasaan sebagai akibatnya otonomi asli yang dimiliki desa adat lokasi berdirinya LPD. Daerah otonomi yang dimilikinya sampai saat ini desa adat akan dapat meningkatkan dirinya terutama dalam melindungi salah satu harta sebagai korban secara langsung. Ikut sertanya pihak luar, seperti Pemda Denpasar, dalam penyelesaian kredit macet justru mengakibatkan belum diatasi, karena mengaburkan cara penanggulangan yang telah dilakukan oleh desa adat setempat. Demikian juga adanya putusan dan badan peradilan formal baik dari Pengadilan Negeri yang menjatuhkan pidana penjara tampaknya belum bisa mengurangi kredit macet dan belum bisa memberikan perlindungan secara langsung pada LPD, karena kerugiannya tidak dapat diseimbangkan dengan pidana penjara. Dengan demikian putusan yang diberikan oleh badan peradilan formal ini tidak sesuai dengan nilai kepatutan yang ada dalam masyarakat dan justru akan dapat menyamarkan putusan telah dikenakan. Oleh karena itu tujuan untuk merealisasikan terpidana 
(jangka pendek) yang menjadi salah satu tujuan dari sistem peradilan pidana tidak akan tercapai, karena sampai saat ini terpidana masih dinonaktifkan sebagai anggota banjar/desa.

Sanksi adat yang tel ah dikenakan akan berakhir jika yang bersangkutan sudah mau mohon maaf kepada warga banjar dan melaksanakan segala bentuk kewajiban yang telah disepakati dalam paruman (Putri et al., 2018). dengan demikian kewajiban untuk melakukan ganti kerugian merupakan amanat dari Pasal 22 Perda Provinsi Bali Nomor 3 Tahun 2007 dan amanat dari awig-awig desa. Oleh karena itu langkah formulasi dan dicantumkannya pidana tambahan berupa pemenuhan kewajiban adat dan kewajiban pembayaran ganti kerugian seperti yang diatur dalam Pasal 60, 89, dan 90 Rancangan KUHP 1993 tampaknya merupakan langkah yang tepat sebagai upaya pembaharuan hukum pidana (materiil ) yang diharapkan mampu memberikan kepastian hukum dan memenuhi rasa keadilan masyarakat, sehingga tujuan dari Sistem Peradilan Pidana akan dapat diwujudkan.

Dari uraian ini dapat dilihat bahwa perubahan hukum pidana yang direncana dan telah diformulasikan secara oprasional bekerja dalam sistem peradilan pidana akan mampu lebih memenuhi rasa keadilan masyarakat dan menghindark an adanya pemberian sanksi doble, karena desa adat di Bali dengan otonomi asli yang dimiliknya sampai sekarang berwenang untuk menyelesaikan sengketa yang terjadi diwilayahnya, terutama yang menyangkut penanggulangan kredit macet melalui penjatuhan sanks i adat seperti yang dilakukan oleh Desa Adat .

Sanksi adat adalah dalam upaya memberikan pendidikan bagi warganya untuk selalu bisa berperilaku pada jalan yang dianggap patut, sehingga kerukunan warga tetap dapat te rjamin. Kondisi ini diciptakan adalah sebagai upaya untuk melindungi LPD sebagai salah satu harta kekayaan desa adat dan sekaligus sebagai korban, sehingga proses pemberdayaan desa adat melalui perlindungan hukum yang dimiliki diharapkan mampu mendukung desa adat yang mandiri, karena dalam perjalanannya banyak biaya yang diperlukan dalam proses pembangunan baik fisik maupun nonfisik. Namun pada akhirnya kembali pada adanya kesadaran dari para individu untuk dapat meresponnya secara positif.

Bedasarakan hasil wawancara tanggal 20 Desember 2019 dengan diperoleh bahwa tujuan dari pengenaan sanksi adat terutama bagi nasabah yang menyebabkan menjadi macet sebagai berikut:

1) Untuk dapat mengamankan danaya yang sekaligus merupakan uang masyarakat, dan uang bantuan pemerintah

2) menumbuhkan kesadaran masyarakat terhadap posisi keuangan Lembaga Perkreditan Desa

3) Membina persatuan dan kesatuan di desa adat

4) Memelihara keajegan dari awig-awig desa adat

5) Untuk mencegah agar masyarakat lain tidak melakukan peniruan terhadap perilaku yang menyimpang terutama tidak ikut-ikutan memacetkan kreditnya

6) Menjadikan pelaku sadar dan segera dapat kembali sebagai warga yang baik dan taat pada hukum

7) Agar pelaku segera dapat menihilkan.

Selanjutnya disampaikan oleh Bendesa Adat bahwa tujuan dan pengenaan sanksi adat adalah:

1. Memberikan pendidikan bagi yang bersangkutan agar dapat kembali pada jalan yang patut, yaitu membayar kembali uang yang telah digunakan.

2. Memberikan pendidikan bagi warga masyarakat lain agar tidak mengikuti jejak yang tidak patut dan mencegah agar perbuatan yang tidak patut tidak ditiru oleh warga lain

3. Memberikan pengayoman pada warga yang baik dan sudah bertindak secara patut.

Fungsi sanksi adat adalah bersifat refresif dengan tujuan menyelesaikan konflik, memulihkan keseimbangan materiil yaitu uang LPD dikembalikan, mendatangkan rasa damai dalam masyarakat dan bebas dari rasa salah pada terpidana melalui permohonan maaf (pengaksama ring ajeng banjar/desa) (Zulfa, 2010). Tindakan ini adalah merupakan suatu tindakan yang sedemikian bijaksana dan yang menunjukkan kebesaran hati dan kesungguhan untuk bertobat. Sikap demikian tampaknya oleh warga masyarakat mempunyai nilai yang tidak bisa diukur, sehingga oleh warga masyarakat yang bersangkutan segera dimaafkan dan selanjutnya dianggap tidak pernah melakukan pelanggaran. Jadi tidak ada, stigma yang timbul berkenaan dengan sanksi adat. Tetapi keadaan ini akan sangat tergantung pada respon yang diberikan oleh individu itu sendiri terutama berkaitan dengan kesadaran, sikap dan perilakunya.

Menurut Suputra et al., (2017) ada dua Langkah yang dilakukan apabila menghadapi masalah kredit macetse bagai berikut: 
a. Mengadakan pendekatan terhadap nasabah, pendekatan ini dimaksudkan untuk mengetahui faktor-faktor penyebab nasabah tidak mampu membayar kreditnya. Apabila disebabkan oleh usahanya yang kurang berkembang sementara telah dilakukan dengan baik atau ada hambatan di luar kemampuan nasabah maka terhadap nasabah yang demikian diberikan perpanjangan waktu pembayaran. Setelah diberikan waktu perpanjangan belum mampu membayar,maka akan dikenakan denda.

b. Setelah dilakukan pendekatan dan pemberian perpanjangan jangka waktu kredit, nasabah belum mampu membayar. Maka pengurus akan menyampaikan keadaan tersebut. Selanjutnya Bendesa Adat akan melakukan perundingan kepada nasabah, apabila perundingan tidak memberi hasil. Upaya terakhir yang dilakukan adalah menerapkan sanksi adat yang terdapat dalam peraturan desa (awig-awig) untuk menyelesaikan kredit macet tersebut.

Fungsi sanksi adat juga dimaksudkan untuk menumbuhkan rasa malu bagi pelanggar sehingga sebagai akibatnya akan timbul rasa "jengah" (respon positif), yaitu segera kembali menjadi warga yang baik seperti diharapkan bersama. Terutama para nasabah dan pelaku kredit macet telah diakui bahwa mereka pada dasarnya merasa takut dan malu dengan pengenaan sanksi adat karena sangat berkaitan dengan nama baik mereka dan keluarganya dan juga menyangkut status mereka di banjar/desa baik pada saat ini maupun masa mendatang. Tetapi rasa malu dan takut ini tidaklah mempunyai arti dan makna apapun jika hanya sebagai lip service belaka, dan tidak direspon dengan positif terutama dengan tindakan nyata untuk segera taat pada norma hukum yang berlaku. Oleh karena itu diperlukan adanya pengawasan secara ketat oleh seluruh komponen dalam masyarakat terhadap "sanksi" adat yang telah dikenakan, karena tiada pengawasan dapat dijadikan peluang untuk menerobosnya. Untuk menjadikan "sanksi" adat dapat berfungsi dengan baik diperlukan adanya komitmen bersama untuk menumbuhkan kesatuan gerak dan langkah diantara prajuru adat, aparat pemerintahan, pengurus, para tokoh masyarakat, dan warga masyarakat dengan berpusat pada tujuan yang akan dicapai, yaitu pemulihan "perimbangan" yang dalam kasus ini lebih bersifat materiil, yaitu keuangan yang notabene sebagai uang masyarakat desa di satu sisi, sedangkan di sisi lain diarahkan kepada usaha-usaha meningkatkan taraf hidup Krama Desa untuk menunjang pembangunan desa.

Pada dasarnya penjatuhan sanksi adat berfungsi represif dengan tujuan melindungi keuangan karena pengurus yang lalai dalam melaksanakan tugas-tugasnya. Tampaknya sampai saat ini yang bersangkutan belum juga mau menyadari bahwa ia harus patuh pada awig-awig desa. Jika saja ia mau melaksanakan apa yang telah disepakati dalam paruman desa, permasalahannya tidak seperti sekarang. Namun bukan berarti terlambat jika ia kembali mau merenungkan tentang apa yang seharusnya dilakukan apabila ia mau sebagai krama banjar/desa kembali, karena sanksi adat akan berakhir setelah penggantian kerugian seperti yang diharusnya oleh Pasal 22 Perda Propinsi Dati I Bali Nomor 2 Tahun 1988 dipenuhi sesuai dengan hasil paruman desa. Adanya sanksi ganda ini memang dimungkinkan oleh Perda Nomor 2 Tahun 1988 karena untuk pengikatan dapat dilandasi oleh awig-awig desa yaitu sebagai konsekuensi logis bahwa LPD sebagai milik desa adat.

Pelanggaran adat yaitu sebagai perbuatan yang oleh masyarakat adat dipandang sebagai perbuatan yang menyimpang terutama dari hasil paruman desa (perarem desa). Oleh karena itu sanksi ganda ini tidak bertentangan dengan Putusan Mahkamah Agung (MA) Republik Indonesia Nomor: 1644K/Pid/1988 tertanggal 15 Mei 1991 yang tidak menerima tuntutan Jaksa Penuntut Umum atas diri terdakwa yang melakukan delik adat, karena sebelumnya telah dijatuhi sanksi adat oleh Kepala Adat (pemuka adat) dan sanksi adat tersebut telah dilaksanakan oleh terdakwa. Hal ini disebabkan materi kasus yang dijadikan dasar penjatuhan sanksi tidak sama. Aturan ini belum bisa dinyatakan memberikan perlindungan kepada korban seperti dalam kasus kredit macet yang telah menimbulkan kerugian. Oleh karena itu alangkah baiknya jika pidana pengganti denda tidak ditentukan secara terbatas, tapi dibuat rumusan yang bersifat umum sehingga dalam pelaksanaannya nanti dapat disesuaikan dengan kerugian yang secara nyata diderita oleh pihak korban. Dengan demikian pemberian pidana oleh badan peradilan formal sekaligus akan mampu melindungi sanksi adat yang telah dilakukan oleh desa adat, sehingga sanksi yang diberikan dalam bentuk pidana akan mencapai tujuannya yaitu konflik yang terjadi bisa diselesaikan, terwujudnya keseimbangan materiil khususnya terhadap sektor riil Badan Usaha Milik Desa Adat yaitu Lembaga Perkreditan Desa, dan terciptanya rasa damai dalam masyarakat. 
Hukum sebagai institusi yang melakukan pengintegrasian terhadap proses-proses yang berlangsung dalam masyarakat, ia menerima masukan- masukan dari bidang ekonomi, politik, budaya untuk kemudian diolah menjadi keluaran yang dikembalikan ke dalam masyarakat dalam bentuk justice (keadilan) (Ariawan, 1992:27). Masukan yang dimaksud disini adalah berupa sengketa atau konflik. Hukum dengan otoritasnya menyelesaikan sengketa tadi sehingga muncul suatu struktur baru yang kemudian dikembalikan dalam masyarakat. Apabila institusi hukum benarbenar hendak berfungsi sebagai sarana pengintegrasian masyarakat, ia harus diterima oleh masyarakat untuk menjalankan fungsinya itu.

Terhadap penyelesaian kasus lembaga perkreditan desa sidakarya oleh peradilan formal, ternyata kurang dapat diterima oleh masyarakat (Sidakarya) karena yang diharapkan oleh masyarakat adalah penyerahan tanah yang dijadikan jaminan pelunasan hutang sebagai ganti kerugian, bukan dalam bentuk pidana penjara. Jika keadaan ini terus berlangsung akan timbul precedent buruk dalam masyarakat, sehingga pengadilan sebagai tempat mencari keadilan tidak akan mendapat kepercayaan lagi.

\section{SIMPULAN DAN SARAN}

\section{Simpulan}

Berdasarkan hasil analisis data, dapat disimpulkan bahwa Pemberian kredit pada lembaga perkreditan desa dengan jaminan hak tanggungan, dituangkan dalam perjanjian kredit antara LPD dan nasabah yang diwajibkan juga mendapat persetujuan dari Bendesa adat, dalam hal ini untuk menerapkan sanksi adat ketika terjadi kredit macet. Kedudukan "sanksi" adat adalah sebagai upaya yang terakhir setelah upaya-upaya lain tidak berhasil dengan tujuan agar kredit macet dapat dilunasi kembali dan Peraturan Gubernur Provinsi bali Nomor 44 Tahun 2017 mengikat terhadap pembebanan hak tanggungan dalam pemberian kredit yang hanya berlaku terhadap Desa adat setempat, dalam hal ini LPD merupakan suatu badan usaha simpan pinjam yang dimiliki oleh desa adat. Oleh karena itu sejak awal dalam perjanjian kredit diupayakan adanya bentuk pengikatan. Jika terjadi kredit macet persoalannya dapat diselesaikan dalam paruman desa dengan menjatuhkan sanksi adat. Penjatuhan sanksi adat ini adalah merupakan bagian dari kekuasaan dalam menyelesaikan setiap pelanggaran atau sengketa yang ada dalam wilayahnya karena otonomi asli, yaitu dalam upaya memberikan perlindungan hukum terhadap salah satu harta kekayaan. Dan nasabah kredit macet yang tidak melaksanakan kewajiban seperti yang dituangkan dalam perjanjian kredit dijatuhkan dengan sanksi sita jaminan yang diikat dengan pembebanan hak tanggungan untuk benda tidak bergerak.

\section{Saran}

Adapun yang menjadi saran yaitu Kepada pihak Lembaga pengkredita desa dalam menaggulangi kredit macet lembaga perkreditan desa dengan penjatuhan sanksi adat kanorayang ke-wusang (dinonaktifkan) sebagai warga (krama) banjar desa dan kesepekang, maka alangkah bijaksananya apabila sebelum adanya penjatuhan sanksi adat, dilakukan pemahaman terhadap sebab-sebab timbulnya kredit macet, karena timbulnya kredit macet tidak hanya disebabkan karena kelalaian dan karakter nasabah tetapi juga karena kelalaian pengurus yang berdampak pada timbulnya krisis kepercayaan masyarakat terhadap lembaga perkreditan desa yang kedua Kepada Desa Adat diharapkan adanya kesetaraan antara fungsi sanksi adat dengan tujuan pemidaan, maka dalam aplikasinya nanti perlu dihindari adanya sanksi secara berganda dalam kasus yang sama sehingga tidak tumbuh pragmentasi dalam proses sistem peradilan pidana.

\section{DAFTAR PUSTAKA}

HS, S. (2014). Perkembangan Hukum Jaminan di Indonesia. Raja Grafindo Persada.

Jayanthi, N. M. D., Wairocana, I. G. i N., \& Wiryawan, I. W. (2016). Status dan Kedudukan Lembaga Perkreditan Desa (LPD) Terkait Pengikatan Jaminan dengan Berlakunya Undang-Undang Nomor 1 Tahun 2013 tentang Lembaga Keuangan Mikro Oleh. Jurnal Ilmiah Prodi Magister Kenotariatan, 1(2), 201-2012.

Maulana, A. F. (2017). Surat Kuasa Membebankan Hak Tanggungan. Jurnal Yuridis, 4(2), 192-204.

Putri, K. A. M. P., Puspitasari, N. W. F., Dewi, N. K. K., Ekarini, N. W., Dewi, I. A. P. P., \& Mertadana, D. P. K. (2018). Pengaruh Hukum Adat atau Awig-Awig Terhadap Pengelolaan Dana Desa di Desa Banjar 
Kecamatan Banjar Kabupaten Buleleng Provinsi Bali. Jurnal Ilmiah Akuntansi Dan Humanika, 8(1), 113.

Soekanto, S. (2009). Penelitian Hukum Normatif. PT Raja Grafindo Persada.

Suputra, K. P., Wahyuni, M. A., \& Herawati, N. T. (2017). Analisis Strategi Penarikan Kredit Macet sebagai Faktor Kunci Berdirinya Kembali Lembaga Perkreditan Desa (LPD). Jurnal Ilmiah Mahasiswa Akuntansi Undiksha, 7(1), 11-22.

Wiguna S, I. G. A. S., Arini, D. G. D., \& Suryani, L. P. (2020). Akibat Hukum Kredit Macet di Lembaga Perkreditan Desa yang Debiturnya Non Krama. Jurnal Analogi Hukum, 2(1), 37-41.

Yandani, N. M. M., \& Suryanata, bI G. N. P. (2019). Pengaruh Penerapan Prinsip-Prinsip Good Corporate Governance dan Budaya Tri Hita Karana Terhadap Kinerja Manajerial Lembaga Perkreditan Desa (Lpd) Pakraman Padang Sambian. Jurnal Ilmiah Akuntansi Dan Bisnis, 4(1), 24-37.

Zulfa, E. A. (2010). Keadilan Restoratif dan Revitalisasi Lembaga Adat di Indonesia. 6(2), 182-203. 